\title{
Zygosity determination in newborn twins using DNA variants
}

\author{
CATHERINE DEROM*, EGBERT BAKKER $†$, ROBERT VLIETINCK*, \\ ROBERT DEROM , HERMAN VAN DEN BERGHE*, MICHELTHIERY , AND \\ PETER PEARSON†
}

From * the Division of Human Genetics, Department of Human Biology, Catholic University of Leuven, Herestraat 49, B-3000 Leuven, Belgium; the Department of Human Genetics, Sylvius Laboratories, State University of Leiden, Wassenaarseweg 72, PB 9503, NL-2300 RA Leiden, The Netherlands; and $¥$ the Department of Obstetrics, State University of Gent, De Pintelaan 185, B-9000 Gent, Belgium.

SUMMARY A prerequisite for the optimal use of the twin method in human genetics is an accurate determination of the zygosity at birth. This diagnosis is sometimes hampered by the lack of available specific markers. We report here the use of DNA variants (restriction fragment length polymorphisms) as genetic markers for zygosity determination. We have analysed the placental DNA of 22 twin pairs with known zygosity on Southern blots by hybridisation with polymorphic human DNA probes. We looked at six different polymorphic sites using four restriction enzymes and six DNA probes. Among 10 dizygotic (DZ) pairs, only one was not demonstrably different and seven had at least two discordances. Within each of the 12 monozygotic (MZ) pairs there was complete concordance. Thus, nine of 10 dizygotic and 12 of 12 monozygotic twins were assigned their correct zygosity solely by comparison of six DNA variants. The use of these highly polymorphic DNA probes may have practical importance for antenatal diagnosis and paternity testing.

Several methods, for example, sex, umbilical cord blood group determination, placental structure, protein enzyme analyses, histocompatibility tests, and dermatoglyphs, are available for the diagnosis of twin zygosity at birth. However, some of these tests have to be performed immediately after birth and call for techniques or equipment often lacking in many hospitals. Methods using samples which could be stored and sent to specialised laboratories if necessary would be useful. Therefore, we looked at the determination of new genetic markers using fresh or frozen placental tissue.

Restriction fragment length polymorphisms (RFLPs) are variations in the size of restriction fragments of genomic DNA that hybridise to specific probes. They are the consequence of changes in the primary DNA sequence, such as single base changes resulting in the introduction or deletion of a restriction site, or the displacement of sites by rearrangements such as insertions, deletions, or translocations. Pedigree analysis has shown that these DNA sequence polymorphisms are inherited

Received for publication 1 August 1984.

Accepted for publication 7 September 1984 as single Mendelian co-dominants. ${ }^{1-3}$ We describe here the use of a set of such sequences as placental genetic markers for zygosity determination in twins at birth.

\section{Materials and methods}

The twin pairs came from a Prospective Twin Survey (PTS) in Gent, sponsored by the local Society of General Practitioners, and numbering 2250 pairs born between July 1964 and July 1983. The diagnosis of zygosity was based on sex, fetal membranes, umbilical cord blood groups, and placental alkaline phosphatase. Same sex dichorionic pairs with at least two different genetic markers were classified as dizygotic.

The DNA probes used were those described by Pearson et al. ${ }^{45}$ These polymorphic sequences (table 1) were obtained by cleaving human placental DNA with EcoRI and isolating and cloning 1 to $2 \mathrm{~kb}$ fragments in the plasmid pBR322. Out of a total of 160 inserts, 23 were unique sequences and 20 of them were assigned to individual chromosomes using a hybrid cell panel. The presence of restriction 
TABLE 1 Polymorphic human DNA probes: gene frequency $\geqslant 0 \cdot 20 .^{45}$

\begin{tabular}{|c|c|c|c|c|}
\hline Probe & $\begin{array}{l}\text { EcoRI insert } \\
(b p)\end{array}$ & $\begin{array}{l}\text { Restriction } \\
\text { enzyme }\end{array}$ & $\begin{array}{l}\text { Chromosome } \\
\text { assignment }\end{array}$ & $\begin{array}{l}\text { Approximate } \\
\text { allele length }\end{array}$ \\
\hline $\mathrm{L} 1.4$ & 725 & EcoRI & 5 & $\begin{array}{l}0.72 \mathrm{~A} \\
0.62 \mathrm{a}\end{array}$ \\
\hline $\mathrm{L} 1 \cdot 22$ & 975 & $\mathrm{BgIII}$ & 1 & $\begin{array}{cc}10 \cdot() & \mathrm{B} \\
7 \cdot() & \mathrm{b}\end{array}$ \\
\hline $\mathrm{L} 1 \cdot 28$ & 1350 & TaqI & $\mathrm{X}$ & $\begin{array}{r}10 \cdot 2 \mathrm{C} \\
9 \cdot 0 \mathrm{c}\end{array}$ \\
\hline L2.7 & 1096 & PstI & 17 & $\begin{array}{rl}7 \cdot 5 & D \\
10 \cdot() & d\end{array}$ \\
\hline $\mathrm{L} 2 \cdot 30$ & 2275 & BglII & 2 & $\begin{array}{l}9.0 \mathrm{E} \\
6.3 \mathrm{c}\end{array}$ \\
\hline L3.8 & 1750 & TaqI & Unknown & $\begin{array}{r}6.5 \mathrm{~F} \\
4.2 \mathrm{f} \\
\text { Del } 0\end{array}$ \\
\hline
\end{tabular}

The upper allele length represents the most frequent variant. Del=deletion.

site polymorphisms was tested on a series of DNA samples isolated from randomly selected placentas. Only the probes with an allele frequency of $\geqslant 0 \cdot 20$ were used for the zygosity determination tests, since they are more discriminating at these higher frequencies. Each estimate of the variant frequencies was based on a total of at least 88 chromosomes. In order to have unrelated subjects, only one child of each twin pair was studied.

Placental DNA was prepared, ${ }^{6}$ digested to completion with an excess of restriction endonuclease (Boehringer, Mannheim), and separated on a $1.0 \%$ agarose gel in $50 \mathrm{mmol} / \mathrm{l}$ tris-acetate, $20 \mathrm{mmol} / \mathrm{l}$ $\mathrm{NaOAc}$, and $2 \mathrm{mmol} / \mathrm{l}$ EDTA (pH 7.8), with a 35 to 45 voltage gradient for 24 hours. DNA transfer to nitrocellulose filters and nick translation of the DNA probes $\left(0 \cdot 5-1 \times 10^{8} \mathrm{cpm} \mathrm{gg}^{-1}\right)$ was performed by standard techniques. ${ }^{78}$ Hybridisation was carried out at $65^{\circ} \mathrm{C}$ for 16 hours, followed by two one hour washes in $2 \times$ SSC, $0.1 \%$ SDS and two one hour washes in $0.3 \times \mathrm{SSC}, 0 \cdot 1 \% \mathrm{SDS}$ at $65^{\circ} \mathrm{C}$. Blots were exposed to a RX medical Fuji $x$-ray film. When necessary, a Kyokko $x$-ray intensifying LH II screen was used with exposure at $-80^{\circ} \mathrm{C}$.

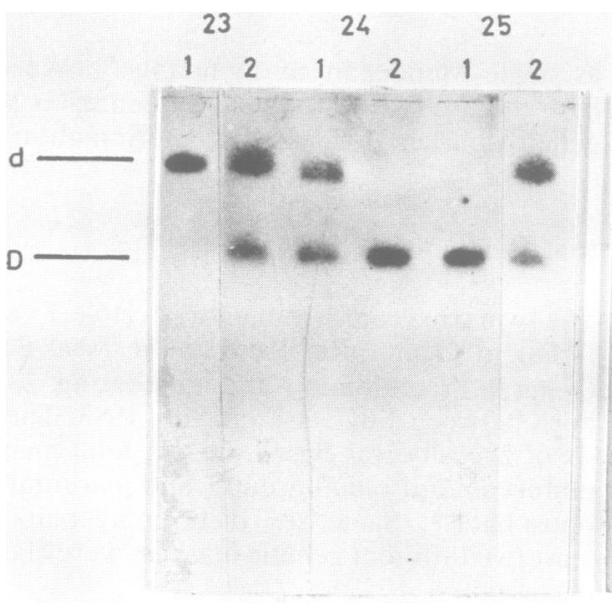

PstI:2.7

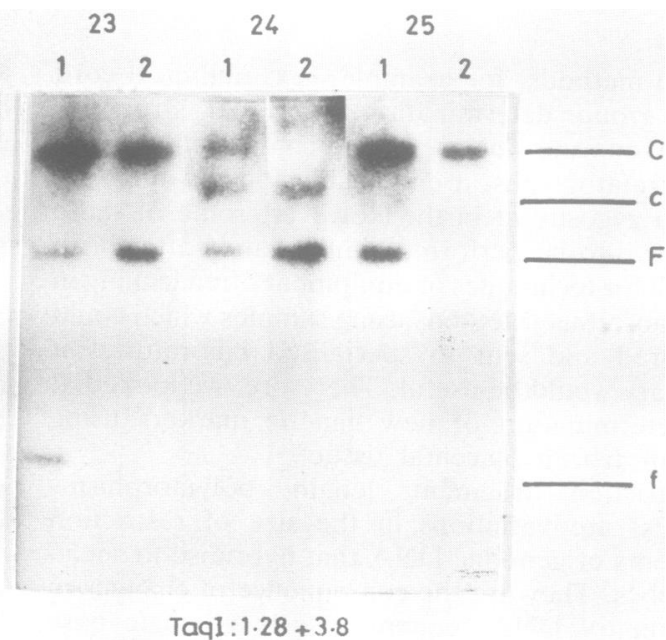

Taql $: 1 \cdot 28+3 \cdot 8$

FIGURE Southern blot hybridisation of total placental DNA from three $D Z$ twin pairs $(23,24,25)$. The different restriction fragments present in each subject are given in letters corresponding to the allele length (table 1). On the left Pstl cleaved DNA was hybridised with the probe L2.7. On the right is the result of a mixed hybridisation of TaqI digested DNA with the probes L1.28 and L3.8. The probes used are polymorphic, human, unique, non-coding sequences cloned in the plasmid pBR322 (table 1); 10 to $15 \mu \mathrm{g}$ of the digested DNA was placed on each lane of a $1.0 \%$ agarose gel and the fragments were separated by electrophoresis. Labelled probes were hybridised to the DNA fragments according to the procedure outlined in Materials and methods. 


\section{Results}

Table 1 lists the approximate allele lengths and the appropriate restriction enzymes for the different probes used. At least five out of six probes were localised on different chromosomes. Their RFLPs were determined at a diallelic locus. In contrast, the L3.8/TaqI polymorphism is a triallelic system, involving a combination of a deletion and a presumptive point mutation. The deletion of this polymorphism could be detected by using a second
DNA probe in the hybridisation reactions as a probe copy standard. This probe recognises a fragment in the same molecular weight range as the deleted fragment, enabling comparison of the intensity of the two bands and distinction between deletion heterozygotes and non-deletion homozygotes.

The hybridisation patterns of probes $\mathrm{L} 2 \cdot 7, \mathrm{~L} 3 \cdot 8$, and $\mathrm{L} 1.28$ are shown in the figure. Table 2 summarises the different variant scores of the representative $\mathrm{DZ}$ (a) and $\mathrm{MZ}$ (b) twin sets. The observed intrapair differences are underlined. Of

TABLE 2 Analysis of the placental DNA of 10 dizygotic (a) and 12 monozygotic (b) twin pairs. The different restriction fragments present in each subject are given in letters corresponding to the allele length (table 1). The observed differences in restriction fragments within a twin pair are underlined. -, not determined.

\begin{tabular}{|c|c|c|c|c|c|c|c|c|c|c|c|c|}
\hline $\begin{array}{l}\text { Restriction } \\
\text { enzyme }\end{array}$ & EcoRI & & BgllI & & & & TaqI & & & & PstI & \\
\hline Probe & $L 1 \cdot 4$ & & $L 2 \cdot 30$ & & $L 1 \cdot 22$ & & $L 3 \cdot 8$ & & $L 1 \cdot 28$ & & $L 2 \cdot 7$ & \\
\hline $\begin{array}{l}\text { Registry } \\
\text { number }\end{array}$ & 1 & 2 & 1 & 2 & 1 & 2 & 1 & 2 & 1 & 2 & 1 & 2 \\
\hline
\end{tabular}

(a) Dizygotic twins

\begin{tabular}{|c|c|c|c|c|}
\hline 2211 & $\mathrm{a} / \mathrm{a}$ & $\mathbf{a} / \mathbf{a}$ & $\mathrm{E} / \mathrm{e}$ & $\mathrm{E} / \mathrm{e}$ \\
\hline 2216 & $\mathbf{A} / \mathbf{a}$ & $\mathrm{A} / \mathrm{a}$ & $\mathrm{E} / \mathrm{E}$ & $\mathrm{E} / \mathrm{E}$ \\
\hline 2217 & $\mathbf{A} / \mathbf{a}$ & $\mathrm{A} / \mathrm{a}$ & $\bar{E} / \mathrm{e}$ & $\mathrm{E} / \mathrm{e}$ \\
\hline 2220 & A/A & $\mathrm{A} / \mathrm{a}$ & $\mathrm{E} / \mathrm{e}$ & $E / e$ \\
\hline 2222 & $\mathbf{A} / \mathbf{A}$ & $\overline{\mathbf{A} / \mathbf{A}}$ & $\mathbf{E} / \mathbf{e}$ & $E / e$ \\
\hline 2223 & A/A & $\mathrm{A} / \mathbf{a}$ & E/E & $\mathrm{E} / \mathrm{E}$ \\
\hline 2224 & $\overline{\mathbf{A} / \mathbf{A}}$ & $\overline{\mathrm{A} / \mathrm{a}}$ & $\mathbf{E} / \mathbf{e}$ & $\mathrm{E} / \mathrm{e}$ \\
\hline 2225 & $\overline{\mathbf{A} / \mathbf{A}}$ & $\overline{\mathbf{A} / \mathbf{A}}$ & E/E & $\mathrm{E} / \mathrm{E}$ \\
\hline 2228 & A/A & $\mathbf{A} / \mathbf{A}$ & $\mathrm{E} / \mathrm{E}$ & E/e \\
\hline 2235 & $\mathbf{A} / \mathbf{A}$ & A/A & $\overline{\mathrm{E} / \mathrm{e}}$ & $\overline{\mathrm{E} / \mathrm{e}}$ \\
\hline
\end{tabular}

(b) Monozygotic twins

\begin{tabular}{|c|c|c|c|c|c|c|c|c|c|c|c|c|}
\hline 2208 & A/A & A/A & $\mathbf{E} / \mathbf{E}$ & $\mathbf{E} / \mathbf{E}$ & B/B & $\mathrm{B} / \mathrm{B}$ & $\mathbf{F} / \mathbf{F}$ & $\mathbf{F} / \mathbf{F}$ & - & - & $\mathrm{D} / \mathrm{D}$ & D/D \\
\hline 2209 & $\mathrm{a} / \mathrm{a}$ & $\mathrm{a} / \mathbf{a}$ & $\mathbf{E} / \mathbf{e}$ & $\mathrm{E} / \mathrm{e}$ & $\mathrm{B} / \mathrm{b}$ & $\mathrm{B} / \mathrm{b}$ & $f / f$ & $\mathbf{f} / \mathbf{f}$ & - & - & $\mathrm{D} / \mathrm{D}$ & D/D \\
\hline 2218 & A/A & A/A & $\mathbf{E} / \mathbf{E}$ & $\mathbf{E} / \mathbf{E}$ & $\mathrm{B} / \mathrm{B}$ & B/B & - & - & - & - & D/D & D/D \\
\hline 2226 & A/A & A/A & $\mathbf{E} / \mathbf{E}$ & $\mathrm{E} / \mathrm{E}$ & $\mathrm{b} / \mathrm{b}$ & $\mathrm{b} / \mathrm{b}$ & $F / 0$ & $F / 0$ & C & C & $\mathrm{D} / \mathrm{d}$ & $D / d$ \\
\hline 2230 & A/A & A/A & $\overline{\mathbf{E}} / \overline{\mathbf{E}}$ & $\mathrm{E} / \mathrm{E}$ & $\mathrm{B} / \mathrm{b}$ & $\mathrm{B} / \mathrm{b}$ & $\mathrm{F} / 0$ & F/0 & $\mathrm{C} / \mathrm{c}$ & $\mathrm{C} / \mathrm{c}$ & D/D & $\mathrm{D} / \mathrm{D}$ \\
\hline 2233 & $\mathrm{~A} / \mathrm{a}$ & $\mathrm{A} / \mathbf{a}$ & $\bar{E} / \mathbf{E}$ & $\mathrm{E} / \mathrm{E}$ & $\mathrm{B} / \mathrm{b}$ & $\mathrm{B} / \mathrm{b}$ & $\mathrm{F} / \mathrm{F}$ & $\mathbf{F} / \mathbf{F}$ & $\mathrm{C} / \mathrm{c}$ & $\mathrm{C} / \mathrm{c}$ & $\mathrm{D} / \mathrm{D}$ & $\mathrm{D} / \mathrm{D}$ \\
\hline 2236 & $\mathrm{~A} / \mathrm{a}$ & $\mathrm{A} / \mathbf{a}$ & $\mathrm{E} / \mathrm{E}$ & $\mathrm{E} / \mathrm{E}$ & B/B & B/B & $\mathbf{F} / \mathbf{F}$ & $\mathbf{F} / \mathbf{F}$ & $\mathrm{C} / \mathrm{c}$ & $\mathrm{C} / \mathrm{c}$ & $\mathrm{D} / \mathrm{D}$ & D/D \\
\hline 2242 & A/A & A/A & $\mathrm{E} / \mathrm{E}$ & $\mathrm{E} / \mathrm{E}$ & $\mathbf{B} / \mathbf{b}$ & $\mathrm{B} / \mathrm{b}$ & F/0 & F/0 & $\mathrm{C} / \mathrm{c}$ & $\mathrm{C} / \mathrm{c}$ & D/D & $\mathrm{D} / \mathrm{D}$ \\
\hline 2244 & A/A & A/A & $\mathrm{E} / \mathrm{E}$ & $\mathrm{E} / \mathrm{E}$ & B/B & $\mathrm{B} / \mathrm{B}$ & $0 / 0$ & $0 / 0$ & $\mathrm{C} / \mathrm{c}$ & $\mathrm{C} / \mathrm{c}$ & $\mathrm{D} / \mathrm{d}$ & $D / d$ \\
\hline 2245 & A/A & A/A & $\mathrm{E} / \mathrm{E}$ & $\mathrm{E} / \mathrm{E}$ & $\mathrm{B} / \mathrm{b}$ & $\mathrm{B} / \mathrm{b}$ & $F / f$ & $\mathbf{F} / \mathrm{f}$ & $\mathrm{ClC}$ & $\mathrm{ClC}$ & $\mathrm{D} / \mathrm{D}$ & D/D \\
\hline 2247 & A/A & A/A & $\overline{\mathrm{E}} / \overline{\mathrm{E}}$ & $\mathrm{E} / \mathrm{E}$ & B/B & B/B & - & - & - & - & - & - \\
\hline 2248 & A/A & A/A & $\mathrm{e} / \mathrm{e}$ & $\mathrm{e} / \mathrm{e}$ & B/B & B/B & - & - & - & - & $D / d$ & $D / d$ \\
\hline
\end{tabular}

TABLE 3 Comparison of DNA variants and blood groups by their overall efficiency: cumulative probability that a DZ twin pair is discordant for the unlinked autosomal loci tested (1-p).

\begin{tabular}{|c|c|c|c|c|c|c|c|c|}
\hline $\begin{array}{l}\text { DNA } \\
\text { variants }\end{array}$ & $\begin{array}{l}\text { Variant } \\
\text { frequency }(\%)\end{array}$ & $p^{*}$ & $p_{1} \times p_{2} \times \ldots$ & $(1-p)$ & Blood group & $p^{*}$ & $p_{1} \times p_{2} \times \ldots$ & $\left(l-p_{1}\right)$ \\
\hline $\mathrm{L} 1 \cdot 22 / \mathrm{BglII}$ & 28 & 0.65 & 0.65 & $0 \cdot 35$ & ABO & 0.67 & 0.67 & 0.33 \\
\hline L2·30/BglII & 20 & 0.71 & 0.46 & 0.54 & Rh & 0.83 & 0.56 & 0.44 \\
\hline L2 -7/PstI & 25 & $0 \cdot 68$ & 0.31 & 0.69 & MNSs & 0.45 & 0.25 & 0.75 \\
\hline L1.4/EcoRI & 22 & $0 \cdot 70$ & $0 \cdot 22$ & 0.78 & $\mathbf{K}$ & 0.90 & 0.23 & 0.77 \\
\hline L1·28/TaqI $\dagger$ & 32 & 0.63 & $0 \cdot 14$ & 0.86 & $\mathbf{P}$ & 0.79 & $0 \cdot 18$ & 0.82 \\
\hline $\mathrm{L} 3 \cdot 8 / \mathrm{TaqI}$ & $26+6$ & $0 \cdot 59$ & 0.08 & 0.92 & Duffy & 0.75 & 0.13 & 0.87 \\
\hline \multicolumn{5}{|c|}{$\begin{array}{l}(1-p)=0.92 \text { or the probability of finding a difference within a DZ } \\
\text { twin pair after testing the six DNA variants is } 92 \% \text {. }\end{array}$} & \multicolumn{4}{|c|}{$\begin{array}{l}(1-p)=0.87 \text { or the probability of finding a difference within a DZ } \\
\text { twin pair after analysing the six blood groups is } 87 \% \text {. }\end{array}$} \\
\hline
\end{tabular}

* $p$ is the probability that a DZ twin pair is alike for the unlinked autosomal loci tested. ${ }^{10}$

+ The probe $\mathrm{L} 1 \cdot 28 / \mathrm{TaqI}$ has been assigned to the $\mathrm{X}$ chromsome. The $\mathrm{p}$ value for this probe has been computed for female pairs. This efficiency is slightly lower in males. To obtain the same efficiency as for females, one can use another autosomal probe with the appropriate variant frequency. 
the 10 pairs of $\mathrm{DZ}$ twins, nine had different restriction patterns and only one was scored as having identical patterns. The DNA discordances ranged from one (in two pairs) to four (in pair 24). Within each of the $12 \mathrm{MZ}$ twin pairs there was complete concordance, indicating that the restriction variants were stable and heritable. Thus, nine of 10 of the $\mathrm{DZ}$ twin pairs were assigned their correct zygosity solely by comparison of the six RFLPs, while complete concordance was achieved in the scores of the $\mathrm{MZ}$ pairs.

To evaluate the efficiency of the DNA polymorphisms studied in distinguishing $\mathrm{DZ}$ from $\mathrm{MZ}$ twins, one can estimate the total probability of a random pair of $\mathrm{DZ}$ twins being concordant for all of the unlinked autosomal loci tested. For each polymorphism, this probability can be calculated according to the number of alleles, their gene frequencies, and their inheritance. ${ }^{910}$ The lower this value, the more efficient a locus is in distinguishing $\mathrm{DZ}$ from $M Z$ twins. The efficiencies of different markers ( $p$ in table 3) can be combined by multiplying their individual efficiencies. As shown in table 3, the twin zygosity determination derived from the scoring of the six DNA polymorphisms is more accurate than after genotyping for the loci of the blood groups ABO, Rh, Kell, Duffy, MNSs, and P. This is in agreement with our results, since nine out of the 10 DZ pairs were assigned their correct zygosity.

\section{Discussion}

This new tool for zygosity determination at birth could have several advantages over conventional methods. (1) Placental tissue is rich in DNA and can be stored at $-20^{\circ} \mathrm{C}$ for long periods of time. In places where there are no facilities for blood group determinations, or in circumstances where it is difficult to send blood to the laboratory, this could be an alternative method of genotyping. (2) Theoretically, the number of polymorphic sites is almost unlimited. Thus, the accuracy of the zygosity diagnosis can be extended at will, as far as unlinked loci are concerned. Furthermore, the use of longer probes should permit longer segments of DNA and many restriction sites to be examined in a single experiment. ${ }^{2}$ The same results can also be obtained by using a set of different polymorphic DNA probes in the same hybridisation mixture. (3) In cases of fetal death, a circumstance in which the detection of conventional genetic markers is difficult or impossible, DNA typing should still remain possible. (4) If any unusual DNA variant were found, enough DNA would also be available to provide a standard for this new variant. (5) Since DNA is readily obtainable, this method could be important when using twins for sib pair linkage studies.

The use of these highly polymorphic DNA probes has other important biological implications. As the variant frequencies $( \pm 30 \%)$ of the minor alleles are high, these RFLPs could be very important in the traditional methods of antenatal diagnosis where DNA is used. The fetal DNA must be differentiated unambiguously from the maternal DNA. This creates some practical problems, which may be solved by the use of a small battery of highly polymorphic probes (table 3 ). Finally, these same RFLPs could also be used for paternity testing.

We thank Professor Elisabeth Robson who suggested the DNA approach, Professor Walter Fiers for allowing several experiments in his laboratory, Ms Rita Desmet for excellent technical assistance, Mr Fred Shapiro for editing, and Ms Greet Otte for typing the manuscript. This research was supported by Grant No 3.0038.82 from the Fonds voor Geneeskundig Wetenschappelijk Onderzoek.

\footnotetext{
References

${ }^{1}$ Little PFR. Antenatal diagnosis of haemoglobinopathies. In: Williamson R, ed. Genetic engineering 1. London, New York: Academic Press, 1981:61-102.

2 Wyman AR, White R. A highly polymorphic locus in human DNA. Proc Natl Acad Sci USA 1980;77:6754-8.

${ }^{3}$ Bell G, Selby M, Rutter W. The highly polymorphic region near the human insulin gene is composed of simple tandemly repeated sequences. Nature 1982;295:31-5.

${ }^{4}$ Pearson P, Bakker E, Flavell R. Considerations in designing an efficient strategy for localizing unique sequence DNA fragments to human chromosomes. Cytogenet Cell Genet 1982;32:308.

5 Scolnick M, Francke U. Report of the committee on human gene mapping by recombinant DNA techniques. Cytogenet Cell Genet 1982;32:194-204.

6 Pearson P, Bakker B, White R, Cavence W, Barker D, Schäfer M. Restriction fragment length polymorphisms and human genetics. Laboratory manual for University of Leiden postgraduate course. Internal report, 1982.

7 Southern E. Detection of specific sequences among DNA fragments separated by gel electrophoresis. J Mol Biol 1975;98:503-17.

${ }^{8}$ Tavernier J, Derynck R, Fiers W. Evidence for a unique human interferon (IFN-B1) chromosomal gene devoid of intervening sequences. Nucleic Acids Res 1981;9:461-71.

${ }^{9}$ Sutton H, Clark P, Schull W. The use of multi-allele genetic characters in the diagnosis of twin zygosity. Am J Hum Genet 1955;7:180-8.

10 Vlietinck R. The determination of zygosity in twins: a practical guide. Eurocat. EEC Brussels, 1979:32-40.
}

Correspondence and requests for reprints to $\mathrm{Dr}$ Catherine Derom, Kwadenplasstraat 20, B-9120 Destelbergen, Belgium. 